\title{
RELIKTNI VRŠAJI KONTAKTNEGA KRASA SEVEROZAHODNEGA DELA MATARSKEGA PODOLJA
}

\author{
Uroš Stepišnik*, Luka Černuta, Mateja Ferk, Petra Gostinčar \\ Oddelek za geografijo, Filozofska fakulteta, Univerza v Ljubljani \\ Aškerčeva 2, SI-I000 Ljubljana, Slovenija \\ *e-mail: uros.stepisnik@ff.uni-lj.si
}

Izvirni znanstveni članek

COBISS 1.01

\section{Izvleček}

Na slovenskem krasu je več različnih tipov kontaktnega krasa. Najpogostejši je ponorni tip kontaktnega krasa, ki se pojavlja med fliši in apnenci. Najdaljši kontakt te vrste v Sloveniji je na območju Matarskega podolja v zahodni Sloveniji, kjer se pojavljajo mnoge kraške globeli, ki so značilne za kontaktni kras. Reliktni vršaji so značilne oblike kontaktnega krasa, ki nastanejo s postopno denudacijo flišne naplavine in kemično denudacijo karbonatne podlage na območjih vršajev. V raziskavi so bile proučene oblike in procesi na vršajih ter vpliv vršajev na razvoj okoliškega krasa.

Ključne besede: kontaktni kras, kras, vršaji, Matarsko podolje, električna upornost tal.

\section{RELICT ALLUVIAL FANS OF NORTWESTERN PART OF MATARSKO PODOLJE}

\begin{abstract}
Several types of contact karst are found within the Slovenian karst, but the most common is the ponor type, which appears between flysch and limestone. The most extensive contact of this type is in western Slovenia, in the area of Matarsko podolje, where a variety of typical contact karst depression features can be found. Relict alluvial fans on contact karst are the result of the gradual denudation of alluvial cover from flysch and chemical denudation of carbonate bedrock in the area of alluvial fans. Geomorphologic features and processes on alluvial fans, and the influences of alluvial fans on the development of local karst have been investigated in detail.
\end{abstract}

Key words: Contact karst, karst, alluvial fan, Matarsko podolje, Electrical resestivity imaging (ERI). 


\section{UVOD}

Najbolj značilen primer ponornega kontaktnega krasa v Sloveniji je Matarsko podolje, ki je relativno uravnana pokrajina med Slavniškim pogorjem in Brkini. Nahaja se v jugozahodnem delu Slovenije. Površinsko in podzemeljsko je Matarsko podolje zakraselo, $\mathrm{v}$ grobem je uravnano in prepleteno $\mathrm{z}$ velikimi udornicami, vrtačami in jamami. $\mathrm{Na}$ severozahodnem obrobju Matarskega podolja med flišem Brkinov in apnenci Matarskega podolja ponira 24 ponikalnic. Stik med flišem in apnenci je pogojeval nastanek niza večjih slepih dolin in ponornih zatrepov (Mihevc 1991). Med jamskimi rovi v zaledju slepih dolin pa prevladujejo brezna, ki so nastala v vadozni coni, ter daljši odseki fosilnih vodoravnih rovov.

V Sloveniji je najpogostejša oblika kontaktnega krasa ponorni kontaktni kras, ki se pojavlja na stiku kraških in nekraških kamnin, pri čemer vode z nekraškega površja tečejo v kras. Tak tip krasa se je razvil na območjih, kjer je nekraško površje višje od kraškega. Hidravlični gradient vode je na teh območjih usmerjen v kras in mora biti manjši od gradienta površja oziroma zniževanja površja v smeri vodnih tokov.

Površinske kraške oblike, značilne za ponorni tip kontaktnega krasa v Sloveniji so slepe doline, ponorni zatrepi (Mihevc 1991), suhe doline, kraški ravniki (Gams 2001) in skupine udornic v kraškem zaledju večjih ponorov udornic (Stepišnik 2006). Kraške jame na kontaktnem krasu prevajajo vodne tokove alogenega izvora in imajo navadno vodoravne rove v epifreatični coni. Na kraškem površju ob kontaktu so pogosti daljši odseki denudiranih vodoravnih jam (Mihevc 2001).

Namen raziskave je bila podrobna proučitev značilnosti kontaktnega krasa na severozahodnem delu Matarskega podolja. Članek podrobno opisuje procese kontaktnega krasa v posebni hidrološki legi, kjer se oblikujejo vršaji. Proučeni so bili pocesi nastanka vršajev na krasu in oblikovanje oblik podobnih vršajem v karbonatni matični podlagi. Za opis površinskih oblik v obliki vršajev na kontaktnem krasu, ki so se oblikovale v karbonatni matični kamini z denudacijo vršajev, uporabljamo termin reliktni vršaji.

Vršaji na krasu niso tipične površinske globeli, kot so ostale oblike kontaktnega krasa, ki nastanejo s korozijo karbonatov. Ti vršaji so edina oblika kontaktnega krasa, kjer pri nastanku niso prevladovali korozijski procesi, pač pa fluvialna akumulacija. Eden izmed vršajev je aktiven, saj se proces sedimentacije še odvija. Flišna naplavina prekriva karbonatno podlago. V tlorisu pahljačaste oblike in konkavnem podolžnem profilu je tipične oblike. Ostali trije vršaji so reliktni. Flišna naplavina je bila na zunanjih delih vršajev denudirana, zato se je na razkritih karbonatnih kamninah začel proces zakrasevanja. Rezultat je izrazito konveksen podolžni profil, kar je značilno za reliktne vršaje na krasu, medtem ko se je ohranil tipičen tloris pahljačaste oblike. Reliktni vršaji do sedaj v krasoslovni literaturi niso bili obravnavani kot tipične oblike kontaktnega krasa.

Raziskava je obsegala podrobno geomorfološko kartiranje območja aktivnega in reliktnih vršajev ter hidrološkega zaledja, ki se nahaja na flišnih kamninah. Podrobno so bili izmerjeni podolžni profili vršajev ter podolžni profil potoka Podseč. V okviru raziskave je bil za potok Podseč izdelan uravnotežen podolžni profil, ki je s primerjavo z izmerjenim podolžnim profilom pokazal nepravilnosti v strugi potoka. Globina rečnih nanosov nad 
karbonatno matično podlago je bila izmerjena z merilcem električne upornosti tal Supersting R1/IP. Uporabljena je bila metoda dipol-dipol s petmetrsko razdaljo med elektrodami, ki se je pri preteklih meritvah v podobnih okoljih izkazala kot najprimernejša. Interpretacija električne upornosti tal je bila izdelana s programskim orodjem EarthImager 2D resistivity inversion software, ki ga je izdelal Advanced Geosciences

Mihevc (1991) omenja, da so vršaji na proučevanem območju morfološko neizrazita oblika kontaktnega krasa. Ugotavlja, da je položna ravnica južno od Slop oblikovana kot vršaj. Flišne naplavine se nahajajo predvsem v vrtačah, vmesna pobočja pa so prekrita $\mathrm{z}$ debelejšo plastjo prepereline kot sosednja površja. Iz tega sklepa, da so bila nekdaj tudi ta površja prekrita s flišnimi naplavinami. Gams (2004) nastanek vršajev na krasu povezuje z hladnejšimi obdobji pleistocena, ko so potoki zaradi intenzivnejšega preperevanja nanašali večje količine materiala. Vršaje na krasu, ki nimajo aktivnega procesa sedimentacije rečnih nanosov na svojem površju, imenuje ,psevdovršaji”.

\section{KONTAKTNI KRAS MATARSKEGA PODOLJA}

Najbolj značilen primer ponornega kontaktnega krasa v Sloveniji je Matarsko podolje, ki se nahaja na jugozahodnem delu Slovenije. Matarsko podolje je relativno uravnana pokrajina med Brkini na severovzhodu, Slavniškim pogorjem na jugozahodu, Matičnim Krasom na severozahodu in Brgundskim podoljem na jugovzhodu. Razpotegnjenoje v smeri severozahod - jugovzhod, dolgo je $18 \mathrm{~km}$ in široko od 2 do $3 \mathrm{~km}$. Nadmorska višina v severnem delu je $290 \mathrm{~m}$, na jugovzhodu pa okrog $640 \mathrm{~m}$ (Slika 1).

Slika 1: Lega proučevanega območja.

Figure 1: The location of the study area.

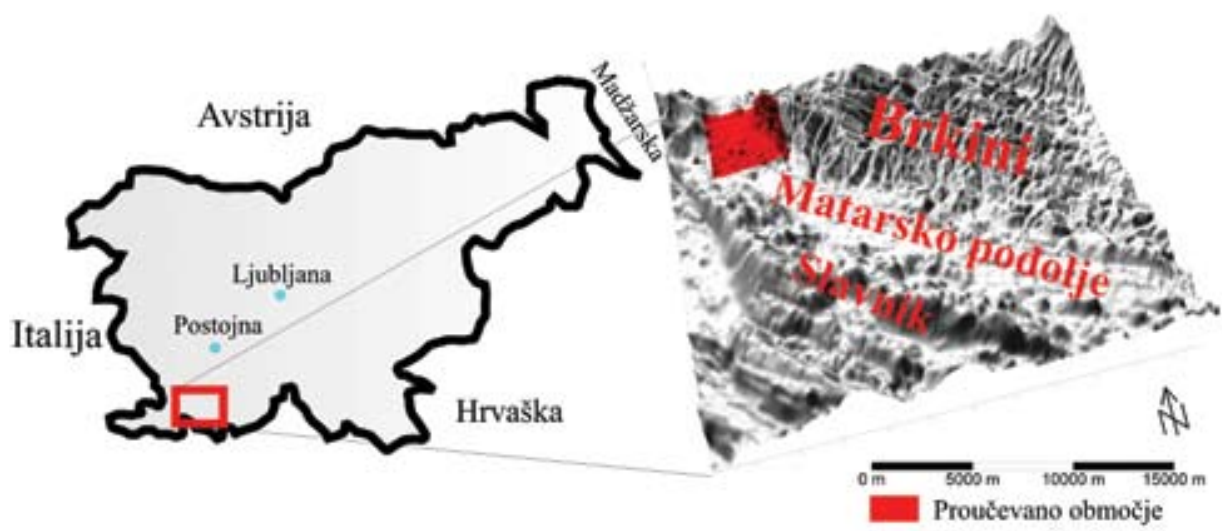

Severozahodno obrobje Matarskega podolja predstavlja stik med karbonatnimi kamninami ter eocenskimi fliši, ki skoraj v celoti gradijo Brkine. Na kontaktu fliš prehaja v paleocenske alveolinske apnence, ti pa $\mathrm{v}$ kredne rudistne apnence, apnence $\mathrm{z}$ roženci ter 
dolomite in apnenčaste breče. Apnenci vpadajo pod fliš s kotom 20 do $60^{\circ}$. Na jugovzhodu prehaja Matarsko podolje v višje Slavniško pogorje, ki ga gradijo kredni apnenci in dolomiti (Pleničar et al. 1975).

Matarsko podolje je najdaljši primer kontaktnega krasa v Sloveniji. Površinsko in podzemeljsko je močno zakraselo, površje je relativno uravnano in prekrito s številnimi vrtačami, velikimi udornicami in jamami (Kranjc 1993; Stepišnik 2006). Na kontaktu med flišem in apnenci, je 24 ponikalnic izoblikovalo niz slepih dolin in ponornih zatrepov (Mihevc 1991). Med dostopnimi jamskimi rovi v zaledju slepih dolin prevladujejo brezna, nastala $\mathrm{v}$ vadozni coni, ter daljši odseki fosilnih vodoravnih rovov, ki so nastali v epifreatični coni. V zaledju slepih dolin je v skupinah razporejenih več kot 80 udornic (Stepišnik 2006). Na površju je veliko daljših odsekov vodoravnih brezstropih jam.

\section{VRŠAJI NA KONTAKTNEM KRASU}

Obravnavano območje leži na skrajnem severozahodnem delu Matarskega podolja. V grobem bi ga lahko razdelili na tri geomorfološke enote: višje flišno območje na jugovzhodu, območje vršajev na krasu ter relativno uravnano kraško površje Matarskega podolja.

$\mathrm{Na}$ flišnih kamninah je prisoten fluvialni geomorfni sistem $\mathrm{z}$ dolinami in vmesnimi slemeni. Flišni greben na obravnavanem območju leži 300 m višje od kraške uravnave Matarskega podolja. Na strmih pobočjih grebena nad vršaji so izoblikovani številni erozijski jarki. Končujejo se na stiku eocenskega fliša in paleocenskih apnencev, pod njimi pa so razviti štirje večji vršaji. Kljub temu, da vode v erozijskih jarkih več ni ali pa je prisotna le občasno, obsežni nanosi prekrivajo paleocenske in kredne apnence v bližini kontakta.

Vrhnji deli proučevanih vršajev so razporejeni vzdolž kontakta fliša in apnenca v dolžini 2,3 km. Na severozahodnem delu območja pri naselju Rodik je aktiven vršaj, ki obsega površino okoli $0,3 \mathrm{~km}^{2}$. Jugovzhodneje se pod večjo erozijsko grapo z ledinskim imenom Celevo, ki prečka greben paleocenskih apnencev, nahaja manjši reliktni vršaj s površino okoli $0,18 \mathrm{~km}^{2}$. Jugovzhodno od nje se nahaja večji reliktni vršaj s površino $1,14 \mathrm{~km}^{2}$, na katerem se v vrhnjem delu nahaja naselje Slope. Na skrajnem jugovzhodu se ob zaključku široke suhe doline Bilendol nahaja manjši reliktni vršaj s površino okoli $0,41 \mathrm{~km}^{2}$ (Slika 2).

$\mathrm{Na}$ vzhodnem delu proučevanega območja je $\mathrm{v}$ bližini kontakta globoko $\mathrm{v}$ fliš vrezan potok Podseč, ki teče v slepo dolino Brezovica. Večina pritokov, ki so se stekali na reliktne vršaje v vzhodnem delu območja, je bila obglavljenih s potokom Podseč. Primerjava uravnoteženega podolžnega profila in dejanskega podolžnega profila potoka je pokazala značilne nepravilnosti v podolžnem profilu potoka, ki se nahajajo na območjih obglavljene suhe doline Bilendol in nekaterih erozijskih jarkov, ki se stekajo na reliktni vršaj pri Slopah (Slika 3).

Literatura navaja vršaje kot akumulacijske oblike, ki so v podolžnem profilu stožčaste oblike in v tlorisu pahljačaste oblike. Nastanejo na mestu, kjer potok ali reka prestopi iz ozke v širšo dolino ali ravnino. Vodotoku se zaradi zmanjšanega strmca močno zmanjša transportna moč in začne odlagati tovor v obliki vršaja (Summerfield 1996; Goudie 2004). Obstaja več klasifikacij vršajev, ki se delijo glede na obliko in starost (Gams 1964; Gams 
2001; Sauro 2001; Goudie 2004). Sedimentacija na vršajih je specifična. Zaradi zmanjšanja transportne moči vodotoka se najbolj grobi sedimenti odlagajo na zgornjem delu vršaja, proti robovom pa se odlaga vse bolj fin material. Tipični vršaj ima podolžni profil konkavne oblike z nakloni v zgornjem delu do $10^{\circ}$, v spodnjih delih pa 1 do $5^{\circ}$ (Bull 1977; Summerfield 1996; Goudie 2004).

Slika 2: Slika proučevanega območja vršajev.

Figure 2: Sketch of the study area with alluvial fans.

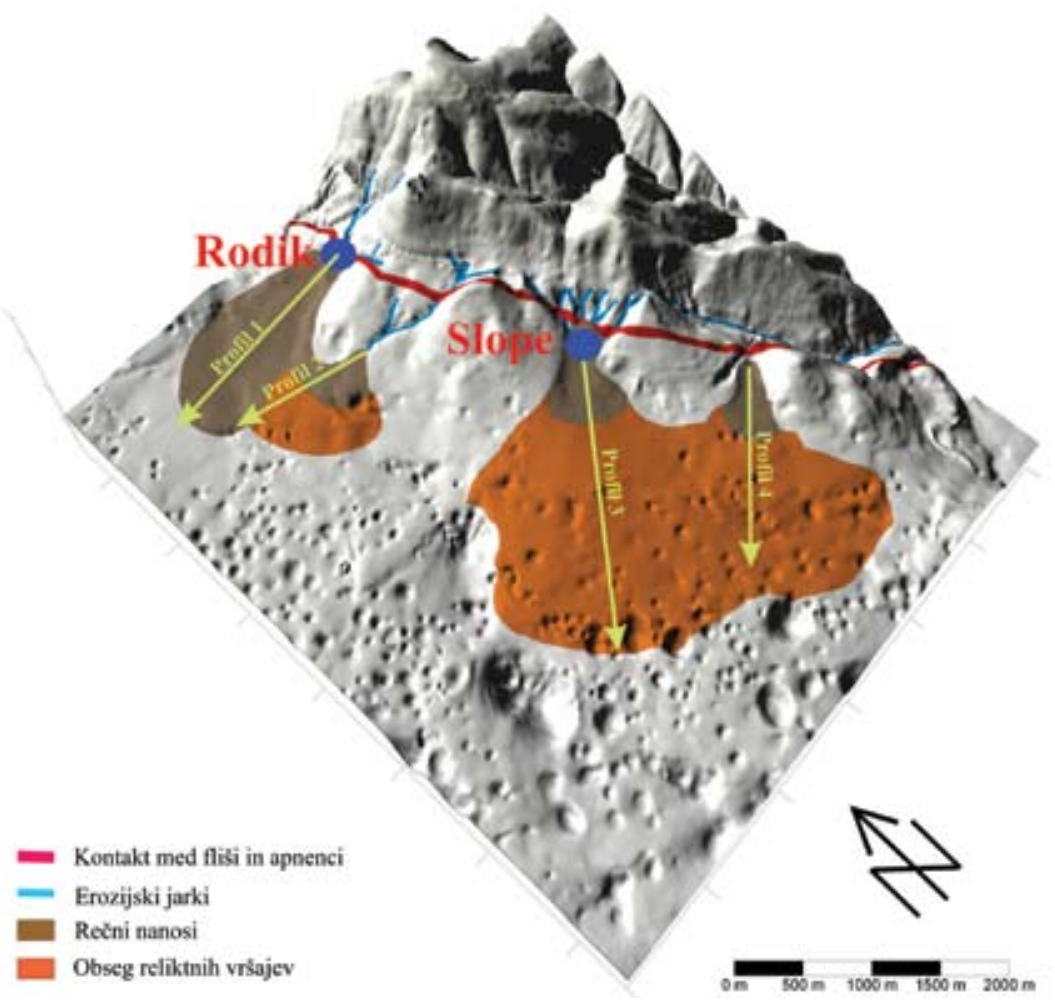

Najbolj tipično obliko vršaja ima aktivni vršaj pri naselju Rodik. Začenja se pod erozijskim jarkom občasnega potoka, ki priteka s strmega flišnega pobočja. Vršaj v celoti gradijo flišni nanosi, zato na njem ni razvitih kraških oblik. V spodnjem delu pa preide v kraško uravnavo. Z oddaljenostjo od vršaja narašča gostota površinskih kraških oblik; veča se gostota in velikost škrapelj, vrtače so številčnejše, večjih dimenzij in z vedno bolj strmimi pobočji. Ob zaključku vršaja se nahaja tudi več vodoravnih jam, ki so delno zapolnjene s flišnimi prodniki in ilovico. 
Slika 3: Uravnotežen in izmerjen podolžni profil potoka Podseč z indeksom neuravnoteženosti podolžnega profila.

Figure 3: Equilibrated and actual longitudinal profile of stream Podseč with equilibration index of longitudinal profile.

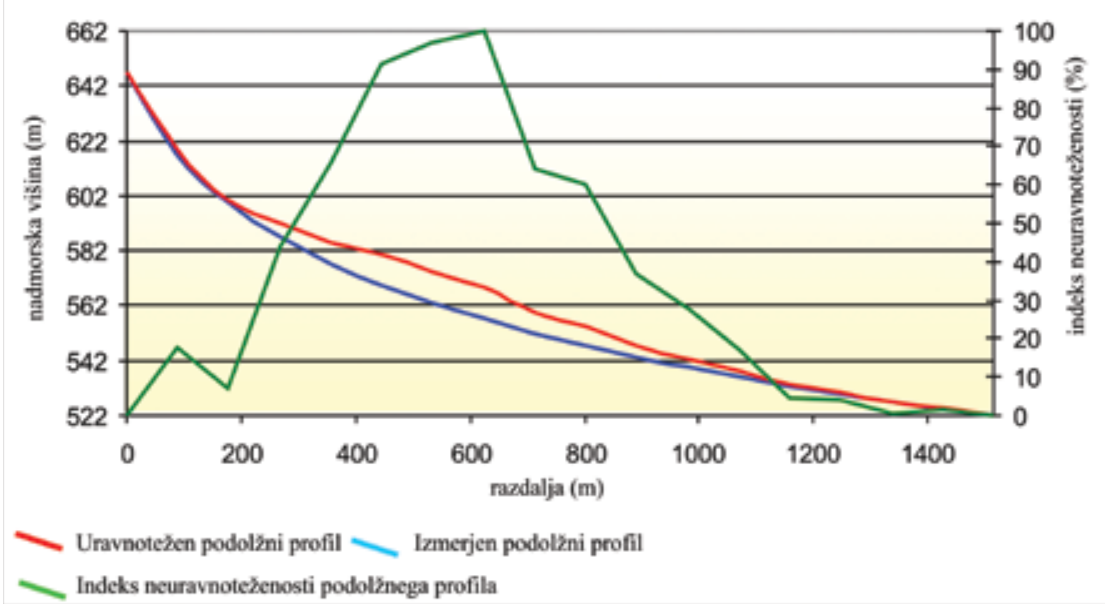

Ostali vršaji na območju so v tlorisu tipično pahljačasto oblikovani. Začenjajo se pod erozijskimi jarki ali pod suho dolino. Zgornje dele teh vršajev gradijo flišni nanosi, v osrednjem in zunanjem delu vršajev izdanja karbonatna matična kamnina. Flišni nanosi se na površju pojavljajo le v manjših zaplatah in na dnu vrtač ter udornic. Z oddaljenostjo od sklenjenih flišnih nanosov narašča tudi površinska zakraselost vršajev. Zgornji deli vršajev so v profilu konkavne oblike, medtem ko so osrednji in spodnji deli konveksni. Ta tip vršajev na krasu v nadaljevanju imenujemo reliktni vršaji.

\section{AKTIVNI VRŠAJ PRI RODIKU}

Edini aktivni vršaj na proučevanem območju je vršaj pri Rodiku, ki po debelini in strukturi naplavine ter oblikovanosti podolžnega profila ustreza oblikovanosti vršajev v fluvialnem geomorfnem sistemu. Naklon v vrhnjem delu je največji in dosega $4^{\circ}, \mathrm{z}$ oddaljenostjo od vrha vršaja pa se naklon zmanjšuje. Globina naplavine, ki je bila ugotovljena z meritvami profilov električne upornosti tal, v vrhnjem delu vršaja presega globino $30 \mathrm{~m}$ (Slika 5, 6 in 7). V tem delu v nanosu flišnih naplavin z manjšo električno upornostjo nastopajo tudi električno bolj uporne plasti, ki so bodisi plasti peska ali proda z manjšo vsebnostjo vode ali pa lokalni izdanek karbonatne matične podlage. Globina nanosov v osrednjem delu vršaja je okoli $25 \mathrm{~m}$, prav tako je manjši naklon. Na zunanjih delih vršaja je površje popolnoma uravnano, razkrita je karbonatna matična kamnina, manjše kotanje v karbonatni kamnini pa zapolnjujejo ilovnati nanosi. 
Slika 4: Podolžni profil vršaja pri Rodiku.

Figure 4: Longitudinal profile of alluvial fan near Rodik.

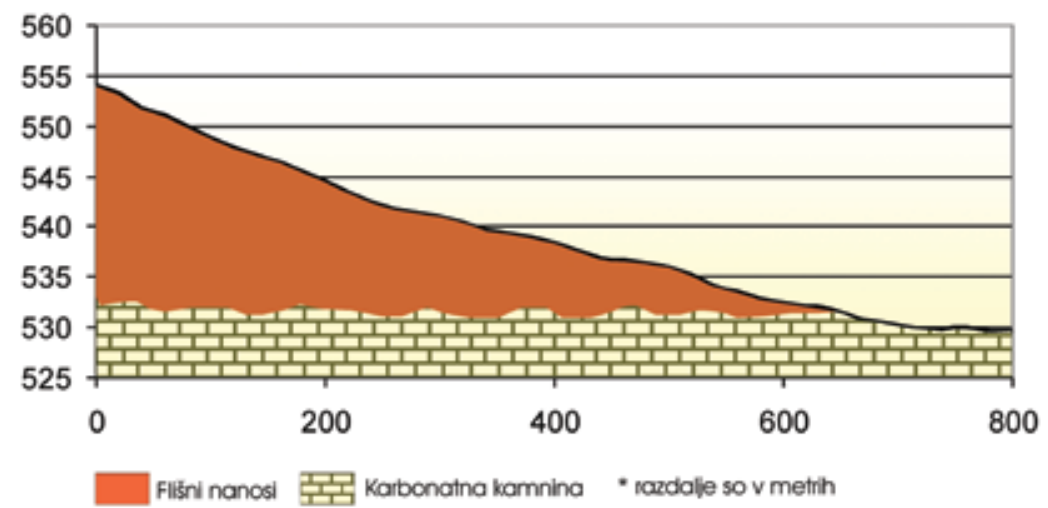

Slika 5: Profil električne upornosti tal preko zgornjega dela vršaja pri Rodiku.

Figure 5: Electrical resistivity profile trough the upper part of alluvial fan near Rodik.

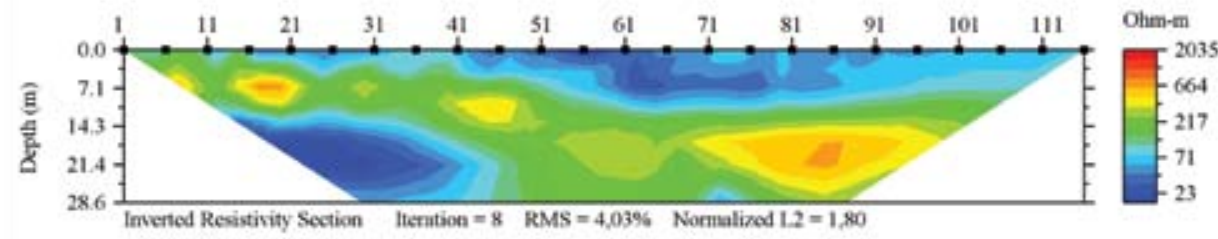

Slika 6: Profil električne upornosti tal preko srednjega dela vršaja pri Rodiku.

Figure 6: Electrical resistivity profile trough the middle part of alluvial fan near Rodik.

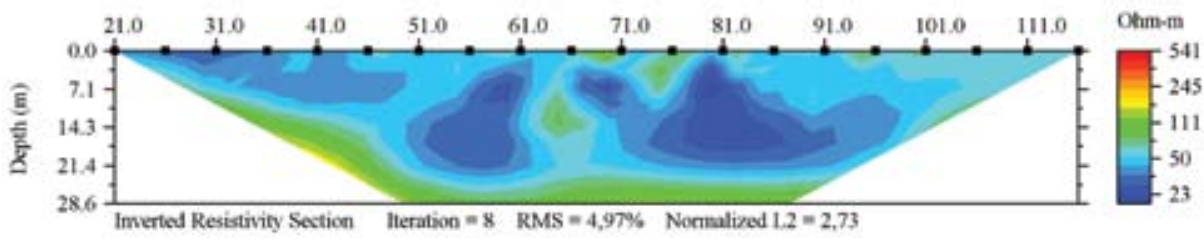

$\square$ Matična kamnina

Flišna preperelina 
Slika 7: Profil električne upornosti tal preko spodnjega dela vršaja pri Rodiku.

Figure 7: Electrical resistivity profile trough the lower part of alluvial fan near Rodik.

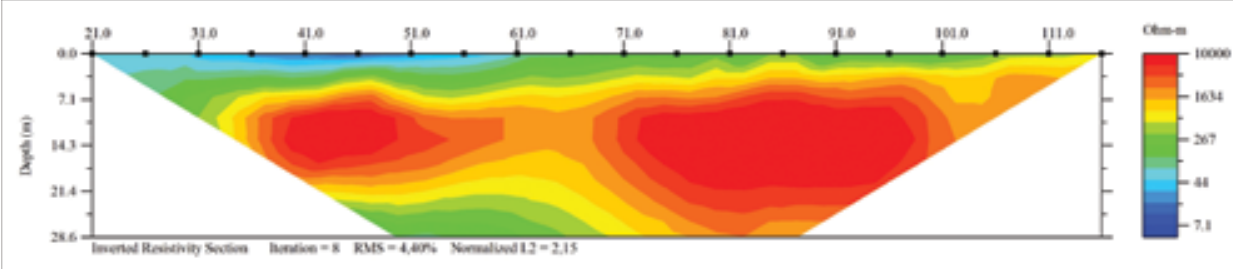

Matična kamnina

Flišna preperelina

\section{RELIKTNI VRŠAJ CELEVO}

Reliktni vršaj Celevo je vršaj z najmanjšo površino na proučevanem območju. Nastal je pod erozijskim jarkom, ki ima topinim Celevo, zato smo tudi vršaj poimenovali z istim imenom. Podolžni profil vršaja je v zgornjem delu, ki ga gradijo flišni nanosi izrazite konkavne oblike. Nakloni površja v tem delu dosegajo do $8^{\circ}$. V srednjem delu vršaja izdanja karbonatna matična podlaga, zaplate flišnih nanosov so obsežne; površinske kraške oblike v tem delu so redke. V tem delu vršaja konkavni podolžni profil prehaja v konveksnega; nakloni pobočij so med 3 in $5^{\circ}$. Spodnji del vršaja na gosto prekrivajo površinske kraške oblike, predvsem škraplje in vrtače. Naklon pobočja preide iz $5^{\circ}$ in v skrajnem spodnjem delu doseže $9^{\circ}$, torej je izrazito konveksno oblikovan. Spodnji del vršaja preide v uravnavo pod aktivnim vršajem pri Rodiku (Slika 8).

Slika 8: Podolžni profil reliktnega vršaja Celevo.

Figure 8: Longitudinal profile of the relict alluvial fan Celevo.

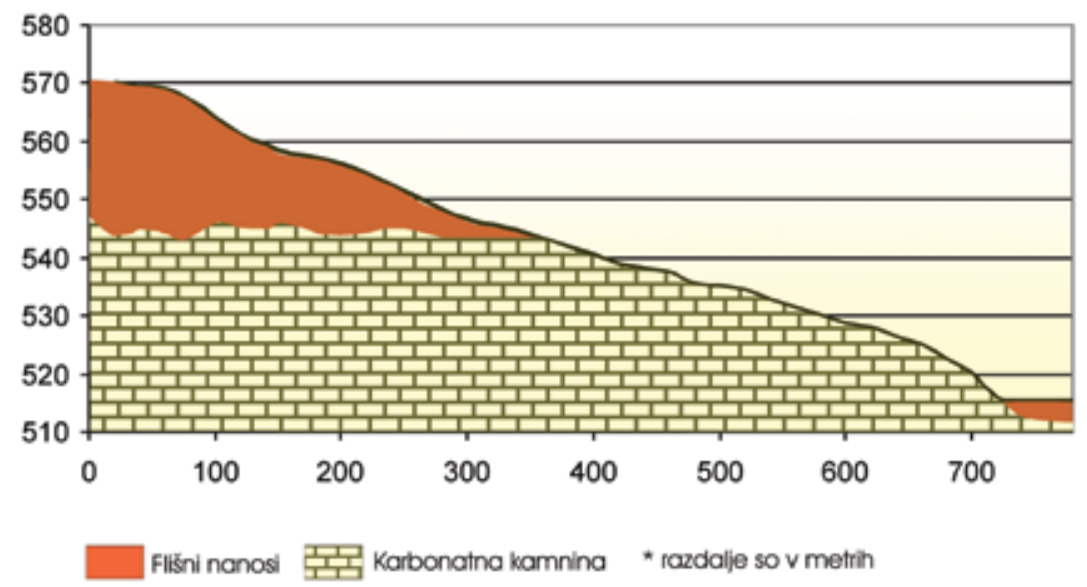




\section{RELIKTNI VRŠAJ PRI SLOPAH}

Vršaj z največjo površino na proučevanem območju je reliktni vršaj pod naseljem Slope. Njegov vrh leži pod številnimi manjšimi erozijskimi jarki v strmem flišnem pobočju nad naseljem Slope. V zgornjem delu je prekrit z debelimi nanosi flišne prepereline, ki presegajo debelino 28 metrov (Slika 9). V zgornjem delu je izrazito konkavne oblike z nakloni do $7^{\circ}$. $\mathrm{V}$ srednjem delu je naklon pobočja do $3^{\circ}$, flišni nanosi pa le v nekaj decimetrov globokih zaplatah prekrivajo karbonatno matično kamnino (Sliki 10 in 11). Na zunanjem delu nakloni dosegajo vrednosti med 6 in $8^{\circ}$, podolžni profil pa je izrazito konveksen. Z oddaljevanjem od flišnih nanosov, ki segajo do osrednjega dela vršaja, narašča zakraselost površja, tako je površje vedno bolj kamnito in vrtačasto.

Slika 9: Podolžni profil vršaja pri Slopah.

Figure 9: Longitudinal profile of alluvial fan near Slope.

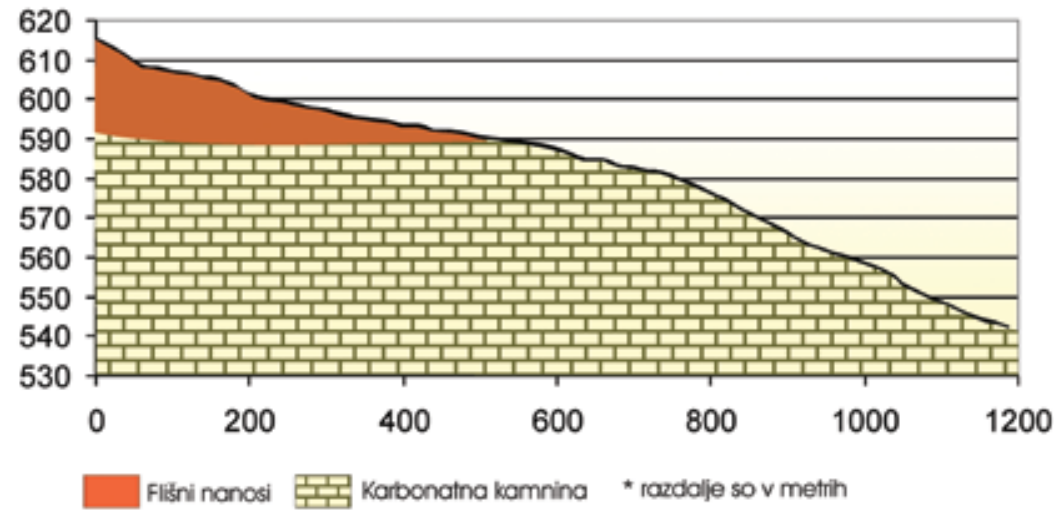

Slika 10: Profil električne upornosti tal preko zgornjega dela reliktnega vršaja pri Slopah.

Figure 10: Electrical resistivity profile trough the upper part of relict alluvial fan near Slope.

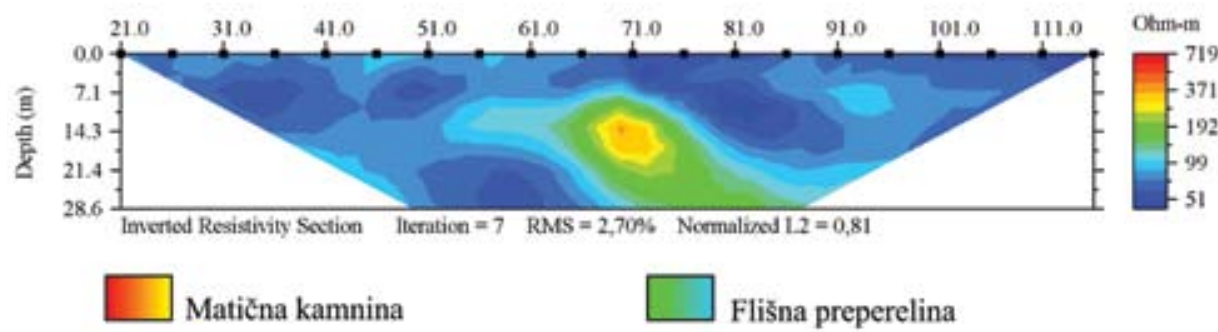


Slika 11: Profil električne upornosti tal preko srednjega dela reliktnega vršaja pri Slopah.

Figure 11: Electrical resistivity profile trough the middle part of relict alluvial fan near Slope.

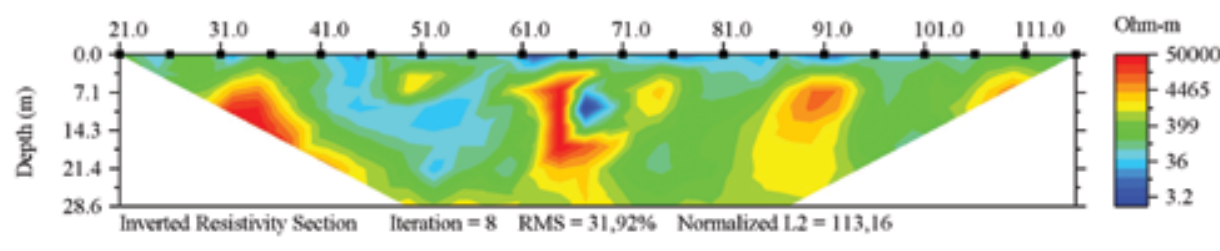

Matična kamnina

Flišna preperelina

\section{RELIKTNI VRŠAJ BILENDOL}

Na skrajnem jugovzhodnem delu proučevanega območja pod suho dolino Bilendol leži izrazit reliktni vršaj, ki ga imenujemo po toponimu suhe doline nad njim. Suha dolina Bilendol nad vršajem je bila obglavljena s potokom Podseč, ki odteka v smeri slepe doline Brezovica. Danes je potok zarezan v dolini, ki leži 30 metrov nižje od suhe doline Bilendol. $\mathrm{Na}$ območju suhe doline je razlika med dejanskim in uravnoteženim podolžnim profilom potoka največja, kar kaže na obglavitev potoka, ki se je stekal na območje reliktnega vršaja Bilendol. Obglavitev je povzročila prekinitev fluvialne sedimentacije na območju vršaja.

Slika 12: Podolžni profil vršaja Bilendol.

Figure 12: Longitudinal profile of alluvial fan Bilendol.

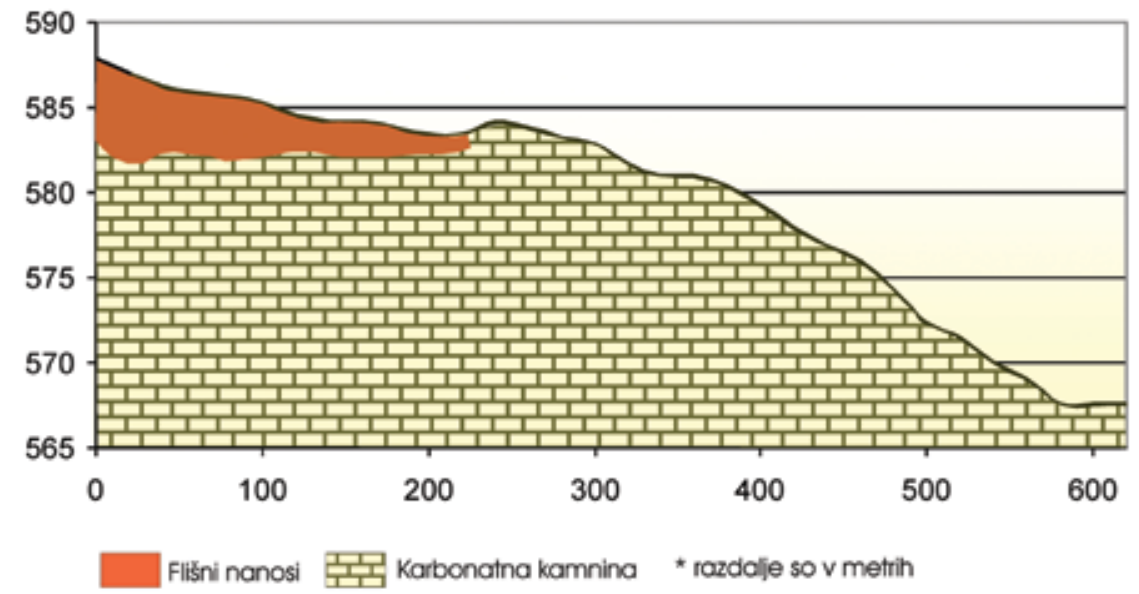


Zgornji del vršaja je prekrit s flišnimi nanosi in je blage konkavne oblike z nakloni do $5^{\circ}$. Območje flišnih nanosov se zaključi z do dva metra visoko morfološko stopnjo, ki jo gradi karbonatna matična podlaga. Flišni nanosi tako zapolnjujejo kotanjo, ki je po vsej verjetnosti manj izrazita slepa dolina. Izvor slepe doline ni jasen, saj se je lahko oblikovala na reliktnem vršaju ali pa je bila oblikovana v karbonatni kamnini že pred nasutjem vršaja.

Osrednji del reliktnega vršaja prekrivajo manjše zaplate flišnih nanosov, naklon vršaja $\mathrm{v}$ tem delu pa je med 1 in $2^{\circ}$. Spodnji del vršaja ima na površju večjo gostoto kraških oblik, predvsem škrapelj in vrtač. Nakloni pobočij dosegajo vrednosti do $6^{\circ}$. Vršaj se zaključi v uravnanem kraškem površju Matarskega podolja.

\section{JAME NA PROUČEVANEM OBMOČJU}

V okolici Slop in Rodika se nahaja okoli 30 jamskih objektov. Največje dimenzije ima $300 \mathrm{~m}$ dolga in $100 \mathrm{~m}$ globoka Cikova jama (kat. št. 971). Ostale natančneje preučene jame so od 20 do $80 \mathrm{~m}$ dolge in od 7 do $50 \mathrm{~m}$ globoke. Danes je nivo piezometra vsaj $100 \mathrm{~m}$ nižje, saj ga ne dosega niti najgloblja jama na proučevanem območju (Kataster jam JZS, 2006).

Prevladujejo vadozna brezna, ki sekajo vodoravne odseke jamskih rovov. Večina vodoravnih jamskih rovov je bila oblikovana $v$ freatični, predvsem pa $v$ epifreatični coni. Ti rovi imajo na stenah fasete različnih velikosti, vendar pa $v$ istih rovih navadno kažejo smer toka v več različnih smeri, zato natančne smeri vodotokov niso določljive. V vodoravnih rovih se pojavljajo uravnana dna z ilovnatim sedimentom. Tisti rovi, ki nimajo uravnanega dna, imajo v posameznih delih sten ostanke ilovnatih in prodnih flišnih zapolnitev.

Ob zaključku vršaja pri Rodiku se nahaja Perčinelova jama (kat. št. 1149) (Kataster jam JZS 2006), ki ima v slepem rovu blizu površja ostanke prodnih in ilovnatih zapolnitev, ki so bile prekinjene z več fazami odlaganja sige. Flišni material različnih velikosti se bil po vsej verjetnosti transportiran iz območja vršaja. Faze vnašanja materiala so bile prekinjene z daljšimi obdobji sedimentacije sige, kar kaže na to, da je jama delovala kot ponor ob koncu vršaja, kjer so vode odtekale v podzemlje. Vsekakor bi bile potrebne podrobnejše analize sedimentov v jamah ob koncu vršajev, da bi ugotovili, kako je deloval odtok vod iz vršajev.

$\mathrm{Na}$ proces vnašanja flišnega materiala $\mathrm{v}$ podzemlje in uravnavanje jamskih rovov $\mathrm{Z}$ ilovnatim materialom na nivoju piezometra kažejo tudi značilnosti številnih drugih jam na obrobju proučevanih vršajev. Vnos flišnega materiala v kraško podzemlje ob zaključkih vršajev in lokalen dvig nivoja piezometra bi lahko dokazovala tudi ilovnata uravnana dna udornic na proučevanem območju (Stepišnik 2006), saj so uravnana na istih nadmorskih višinah kot so z ilovnatim materialom uravnani jamski rovi (Kataster jam JZS 2006).

\section{SKLEPI}

Na proučevanem območju smo na površju identificirali štiri izrazitejše oblike vršajev. Na severozahodnem delu območja pri naselju Rodik je preko karbonatne matične podlage nasut material vršaja, na katerem je prisotno recentno nanašanje materiala. Ob kontaktu med flišnimi in karbonatnimi kamninami proti jugovzhodu pa si sledijo tri na videz podobne 
površinske oblike, ki so oblikovane v karbonatni podlagi. V teh primerih ne gre za tipične vršaje, ki jih gradi fluvialni sediment, pač pa so se v karbonatni matični podlagi ohranile oblike vršajev, ki so bili nekoč razviti na tem površju. Te oblike vršajev v karbonatni matični podlagi smo poimenovali reliktni vršaji.

Vršaji so značilne akumulacijske oblike fluvialnega geomorfnega sistema. Podolžni profili vršajev so običajno konkavne oblike, v tlorisih so pahljačasti. Edini vršaj, ki ima na proučevanem območju še aktivno nanašanje materiala $s$ fliša, je vršaj pri Rodiku. Po obliki je tipičen vršaj, kakršni so prisotni v fluvialnem geomorfnem sistemu. Začenja se pod erozijskim jarkom potoka z Brkinov. Naklon je sprva največji in dosega vrednosti do $4^{\circ}$, nato se postopno zmanjšuje vse dokler ne preide v kraško uravnavo kjer ima naklon $0^{\circ}$. Podolžni profil vršaja pri Rodiku je izrazito konkavne oblike, v tlorisu pa je pahljačaste oblike.

Zgornje dele proučevanih reliktnih vršajev gradijo flišni nanosi, v osrednjem in zunanjem delu pa pokrov prepereline ni sklenjen in izdanja karbonatna matična kamnina. V tlorisu imajo tipično pahljačasto obliko, kot je značilno za vršaje. Zgornji deli vršajev, ki so grajeni iz flišnih nanosov, so v podolžnem profilu konkavnih oblik, osrednji in spodnji deli, kjer izdanja karbonatna matična podlaga, pa so v profilu konveksnih oblik. Konveksna oblika v spodnjih delih profilov reliktnih vršajev se je najverjetneje razvila zaradi prekinitve procesa nanašana materiala na vršaje oziroma oblikovanja vršajev. Ker debelina flišne naplavine upada $z$ oddaljenostjo od najvišje točke vršaja, bo le-ta iz robnih delov vršaja, zaradi denudacijskih procesov najhitreje odstranjena. Razkrita matična kamnina bo ob odstranitvi kamnine podvržena procesu kemične denudacije zaradi padavinske vode. Konveksno obliko srednjih in spodnjih delov profilov reliktnih vršajev lahko razložimo z dinamiko zniževanja površja. Razkrita matična kamina hitreje kemično denudira, kot območja matične kamnine, ki jih prekriva flišna preperelina, torej se bo naklon v spodnjih delih profila vršaja večji.

Izoblikovanje vršajev na proučevanem območju ponornega kontaktnega krasa med Brkini in Matarskim podoljem je posebnost, saj so se sicer po vsem kontaktu izoblikovale slepe doline. Oblikovanje vršajev je vezano na intenzivnejšo erozijo in nanašanje fluvialnega materiala na kraško površje. V tem delu kontaktnega krasa Matarskega podolja so flišni Brkini najvišje nad kraškim površjem, zato je bil transport fluvialnega materiala na kras intenzivnejši, kot v območjih, kjer so se oblikovale slepe doline.

Razvoj oblik, ki smo jih opredelili kot reliktne vršaje, je vezan na prekinitev fluvialne akumulacije alohtonega materiala na krasu in postopno preoblikovanje fluvialne oblike $\mathrm{z}$ denudacijo alohtonih nanosov v obliko na karbonatni podlagi. Ker je matična kamnina $\mathrm{v}$ zgornjem delu zaščitena pred kemično korozijo s fluvialnimi nanosi, se v matični podlagi razvije izrazit konveksen profil vršajev. Tlorisna pahljačasta oblika vršajev pa se v karbonatni kamini ohrani.

Reliktni vršaji do sedaj niso bili obravnavani kot tipične oblike kontaktnega krasa, čeprav je proces njihovega oblikovanja vezan izključno specifične razmere na kontaktnem krasu. Z raziskavo smo prispevali k opisu oblik reliktnih vršajev, tako da bo pri prihodnjih raziskavah lažja identifikacija teh oblik na drugih območjih. Hkrati pa lahko mehanizme nastajanja reliktnih vršajev apliciramo tudi pri interpretaciji akumulacijskih oblik na kraških geomorfnih sistemih z drugačno dinamiko. 


\section{Zahvala}

Avtorji se zahvaljujemo dr. Andreju Mihevcu za koristne nasvete in za merilec električne upornosti tal Supersting R1/IP, s pomočjo katerega smo delno pojasnili razvoj proučevanih oblik. Najlepše se zahvaljujemo tudi študentom geografije Oddelka za geografijo Filozofske fakultete Tomažu Štembergarju, Karmen Peternelj in Urši Ilič za pomoč pri geomorfološkem kartiranju in izdelavi podolžnih profilov vršajev.

\section{Viri in literatura}

Bull, W. 1977: The alluvial-fan environment. Progress in Physical geography 1. London. Encyclopaedia of Geomorphology 2004. New York.

Gams, I. 1964: Klasifikacija vršajev. Geografski obzornik 11. Ljubljana.

Gams, I. 2001: Notion and forms of contact karst. Acta carsologica, 30. Ljubljana.

Gams, I. 2004: Kras v Sloveniji v prostoru in času. Ljubljana.

Kataster jam JZS 2006. Jamarska zveza Slovenije. Ljubljana.

Mihevc, A. 1991: Morfološke značilnosti ponornega kontaktnega krasa, Izbrani primeri s slovenskega krasa. Magistrska naloga, Filozofska fakulteta Univerze v Ljubljani. Ljubljana.

Pleničar, M., Šikić, D. 1975: Osnovna geološka karta 1: 100.000, Tolmač za list L 33 - 89, Ilirska Bistrica. Beograd.

Sauro, U. 2001: Aspects of contact karst in the Venetian fore-Alps. Acta carsologica 30. Ljubljana.

Stepišnik, U. 2006: Udornice na Slovenskem krasu. Doktorska disertacija, Filozofska fakulteta Univerze v Ljubljani. Ljubljana.

Summerfield, M. A. 1996: Global geomorphology, An introduction to the study of landforms. London.

\section{RELICT ALLUVIAL FANS OF NORTWESTERN PART OF MATARSKO PODOLJE}

\section{Summary}

In Slovenia the most common form of contact karst is the ponor type of contact karst, where waters from a non-karstic catchment flow onto the karst surface. Such karst has developed where the non-karstic surface is at a higher elevation or where the hydraulic gradient of water is directed into the karst and is higher than the surface gradient (Mihevc, 1991).

The aim of the research was a detailed investigation of aspects of a contact karst area in the northwestern part of the Matarsko podolje in western Slovenia, where four alluvial fans have been revealed. The alluvial fans in this part of the Matarsko podolje have formed because the Brkini Hills in this area are highest above flattened karst surface of Matarsko 
podolje. This has resulted in intensive erosion processes and input of alluvial material to the karst. Due to the intense material input the waters do not form blind valleys, but instead form alluvial fans.

One of the fans is has an active process of alluvium sedimentation, so alluvial flysch sediment is covering the carbonate bedrock forming a typical fan-shaped landform in ground plan. The other three fan-like surface features are relict. Alluvium from the outer sections of the fans has been denuded, and the process of denudation of the uncovered limestone bedrock has begun. The result of gradual removal of alluvium cover and chemical denudation of exposed carbonate bedrock is a typical longitudinal shape that is characteristic of relict alluvial fans.

Detailed investigation of the contact karst in the northwestern part of Matarsko podolje revealed that the process of alluvial fan formation is in general the same on karst as in fluvial geomorphologic systems. An alluvial fan is concave in shape if the dynamics of sedimentation of the fan are greater than the dynamics of the sediment cover denudation. Where the sedimentation dynamics of the fan are lower or completely static the sediment cover is gradually denuded. The thickness of alluvial cover is lowest in the outer sections of the fans; thus the period of limestone bedrock exposure to chemical denudation will be longest. The result of this process is the formation of a convex longitudinal profile in the outer sections of relict alluvial fans. The final outcome, if all of the alluvial cover is denuded, is a geomorphic feature that is fan shaped in ground plan and convex in longitudinal profile.

Relict alluvial fans on the karst surface have not previously been interpreted as forms typical of contact karst, even though the process of their formation is exclusively related to contact karst. The alluvial fans in the study area can be used as an example for the interpretation of the alluvial fan formation mechanisms on other dynamic karst surfaces. 